\title{
The Impact of the COVID-19 Pandemic on
} Examination of Pregnant Women (Antenatal Care): A Literature Review

\author{
Siti Roudhotul Jannah ${ }^{1}$, Aini Ahmad ${ }^{2}$ \\ ${ }^{1}$ Faculty of Health Sciences, University Islamic Boarding School Darul 'Ulum ,Jombang, Indonesia \\ ${ }^{2}$ School of Nursing KPJ Healthcare University College, Negeri Sembilan, Malaysia \\ Corresponding author: Siti Roudhotul Jannah (email : roudho.26@gmail.com). \\ This work is partly supported by the University of Pesantren Tinggi Darul 'Ulum Jombang.".
}

\begin{abstract}
COVID-19 pandemic is making universal, radical, and very rapid changes in the health services of many countries around the world, especially obstetrics. The World Health Organization states that Coronavirus Disease 2019 (Covid-19) is a global pandemic. As one of the vulnerable groups, pregnant women need to avoid Covid-19 transmission and maintain their health in the pandemic period. The purpose of the study was to look at some of the research together and gain a frame of mind in solving problems about antenatal care in the time of the covid-19 pandemic. Research methods using literature review studies are obtained through the database of international journal providers Proquest and Jurnal Scientific Indonesia through google scholar with keywords according to MESH (Medical Subject Heading) namely "Pandemic Covid-19", "Antenatal Care". As a result of 12 studies, 8 showed negative ratings in which respondents did not make antenatal care visits citing fear of being infected with the virus, felt antenatal care was inadequate and caused great emotional damage to users. 2 of the 8 articles have also implemented online-based health care methods, using smartphone apps specifically designed to be used as a medium for sending health messages so that pregnant women can monitor the health of their pregnancies. As well as reducing direct interaction during the Covid-19 pandemic without compromising pregnancy outcomes. So that optimal education is needed from health workers, to increase the awareness of respondents in determining good behavior during pregnancy in order to undergo pregnancy and childbirth well.
\end{abstract}

INDEX TERMS Covid-19 pandemic, Antenatal Care (ANC).

\section{INTRODUCTION}

Coronavirus (COVID-19) disease pandemic [1]. Coronavirus is a group of viruses derived from the subfamily Orthocronavirinae in the family Coronaviridae and the order Nidovirales that can attack humans and animals [2]. WHO (World Health Organization) has designated the COVID-19 pandemic as a public health emergency of international concern [3] [1].

Indonesia is also one of the countries affected by this outbreak. Therefore, the government needs to take action and the need for awareness from the public so that the number of spread of the virus can be suppressed. Lockdown is considered more effective to prevent the spread of the virus from spreading [4], rather than social restrictions that are still prone to spread because many people do not want to follow the rules because in essence it is just an appeal and there are no severe sanctions that can make the community obedient.
World data said as many as 149 million total cases, as many as 128 million declared cured, as many as 3 million declared dead and active cases as many as 19 thousand. In Indonesia as many as 1.7 million total cases, as many as 1.5 million declared cured, as many as 45 thousand declared dead and active cases as many as 100 thousand.[5] According to data from the east Java health office, 127,856 were treated as of April 1, 2021, 9,024 cases were treated, 7,315 were declared suspects, 127,856 were declared cured and as many as 9,947 were said to have died. In jombang district recorded that as many as 4,551 cases were treated, as many as 4,003 were declared cured and as many as 490 were said to have died.[6] The rapid spread of the virus is mediated by the main reservoirs alphacoronavirus and betacoronavirus that have the ability to infect humans. Close contact with someone infected with COVID-19 will facilitate the process of transmission of COVID-19 between humans. The process of 
transmission of COVID-19 is caused by droplets of someone infected with the SARS-CoV-2 virus into the air when coughing or sneezing, then inhaled by others who are not infected with COVID-19 nearby. Furthermore droplets enter through the nose or mouth through the lungs and the process of infection in healthy humans continues.[7] Clinically, the representation of the virus infection in a person ranging from the presence of asymptomatic gelaja to severe pneumonia, respiratory disorders, septic shock and multiorgan failure that leads to death.[8]

So far preventive efforts are the best practice to reduce the impact of the COVID-19 pandemic, because there is no treatment that is considered effective in fighting the SARSCoV-2 virus. Preventive efforts include avoiding exposure to the virus through PHBS (Clean and Healthy Living Behavior). The main steps that people want to take to achieve the tuuan such as the use of masks, covering the mouth and nose when sneezing or coughing, washing hands regularly using soap or hand sanitizer containing 60\% alcohol, avoiding contact with an infected person, maintaining distance and not touching the eyes, nose, and mouth with unclean hands [9].

ANC is an activity to check the condition of the mother and fetus regularly during pregnancy and detect if there are irregularities.[10] ANC should be done at least 4 times during pregnancy, namely 1 time in the first trimester, 1 time in the second trimester and 2 times in the third trimester.[11] In this COVID-19 pandemic situation, many restrictions in almost all services including maternal and neonatal health services cause pregnant women to become reluctant to go to health care facilities for fear of contracting it. The high risk of infection from severe acute respiratory syndrome coronavirus 2 (SARS-CoV-2) in health services is particularly impactful for mothers who are just giving birth and pregnant women currently needing professional antenatal care.[1] During pregnancy there is a decrease in immunity, resulting in pregnant women more susceptible to viral infections. Physical and immune changes that occur as normal components of pregnancy can have an effect that increases the risk of obstetric complications in pregnant women.[12] This is at risk of complications in the mother during pregnancy in the form of respiratory disorders such as decreased pulmonary and cardiovascular work systems such as the occurrence of tachycardia [13], even nutritional deficiencies [12].

Based on data from the Indonesian Ministry of Health (Kemenkes RI) pregnancy examination visits also decreased, even only $19.2 \%$ of posyandu were still active during the pandemic.[14] Whereas one of the effective solutions in reducing maternal mortality (AKI) and infant mortality (AKB) is to increase maternal participation and awareness of the importance of pregnancy examinations in health care facilities.

From this, it is necessary to conduct an in-depth study to find out the behavior of pregnant women in pregnancy examination (Antenatal Care) during the Covid-19 pandemic due to the many restrictions on routine services including maternal and neonatal health services. As well as the fear of pregnant women against the dangers of this disease. Based on this, it is important to know how the regularity of pregnant women in checking their pregnancies during the Covid-19 pandemic in health care facilities as one of the effective solutions in reducing maternal mortality (AKI) and infant mortality (AKB). The research was taken for analysis through literature review.

\section{METHODS}

Researchers conduct an examination of articles that are in accordance with the isue to be studied. Determination of literature search keywords (search string) based on $\mathrm{PI}(\mathrm{E}) \mathrm{COT}$ framework $(\mathrm{P}=$ patient / problem; $\mathrm{I} / \mathrm{E}=$ exposure/implementation; $\quad \mathrm{C}=\quad$ control/comparison intervention, $\mathrm{O}=$ outcome, $\mathrm{T}=$ time) because a good question will help determine the scope of the review and help the strategy of finding the article.

Articles used in literature review are obtained through the database of international journal providers (Proquest and Jurnal Scientific Indonesia) through google scholar. The author opens the www.Search.Proquest.com website and www.google scholar.com. Researchers wrote keywords according to MESH (Medical Subject Heading) namely "Covid-19 Pandemic", "Antenatal Care", and selected full text.

1. Inclusion Criteria

a) Population or sample is pregnant women at all gestational ages.

b) Discussing pregnancy examination (Antenatal Care) during the Covid-19 pandemic

2. Exclusion Criteria

a) Population or sample other than pregnant women.

b) Discussing pregnancy screening (Antenatal Care) outside the Covid-19 pandemic.

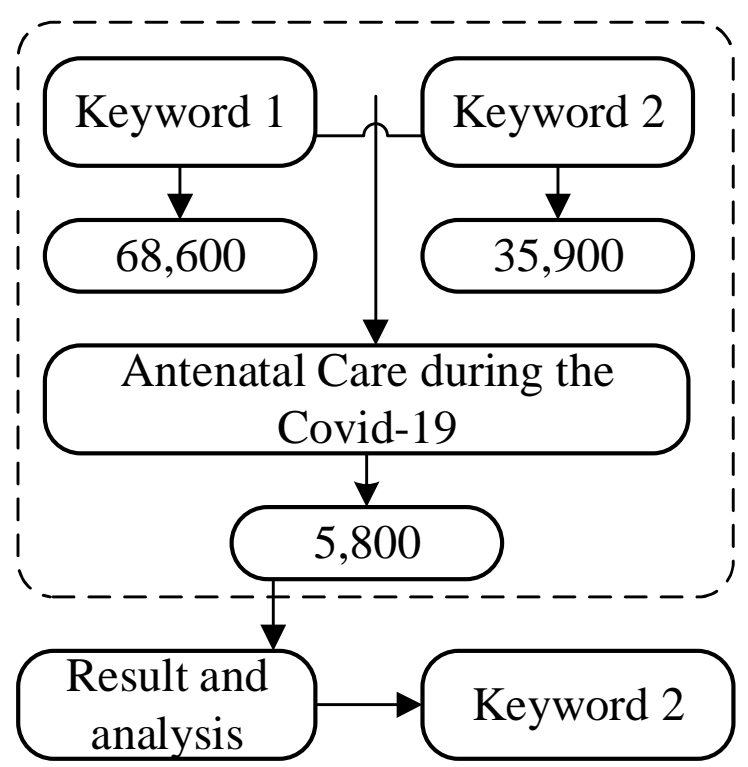

FIGURE 1. The Process of Retrieving Literature Articles 
III. RESULTS

From the search results with the first keyword (Covid-19 Pandemic) found 68,600 articles from 2020. And from the second keyword (Antenatal Care) found 35,900 articles from 2020. And from the combination of the keywords of the two, namely antenatal care during the covid 19 pandemic found

TABLE 1

Journal Article Analysis

\begin{tabular}{|c|c|c|c|c|c|}
\hline No & Author & Title & Method & Procedur & Result \\
\hline 1. & $\begin{array}{l}\text { Palmar, K.R., et } \\
\text { al } \\
(2021)[2]\end{array}$ & $\begin{array}{l}\text { Widespread } \\
\text { Implementation } \\
\text { of A Low-Cost } \\
\text { Telehealth } \\
\text { Service } \\
\text { in the Delivery of } \\
\text { Antenatal Care } \\
\text { During the } \\
\text { Covid-19 } \\
\text { Pandemic: an } \\
\text { Interrupted Time- } \\
\text { Series Analysis }\end{array}$ & $\begin{array}{l}\text { Design : } \\
\text { Interrupted Time- } \\
\text { Series Design } \\
\text { Respondent : } \\
\text { Pregnant women } \\
\text { between April } 20 \\
\text { - July 26, } 2020 \text { as } \\
\text { many as } 2922 \\
\text { pregnant women. }\end{array}$ & $\begin{array}{l}\text { The impact of telehealth } \\
\text { integration was assessed into } \\
\text { antenatal care by analysis of } \\
\text { routinely collected health data } \\
\text { on all women giving birth at } \\
\text { Monash Health, a major health } \\
\text { service in Victoria (Australia). } \\
\text { By comparing the first } 3 \\
\text { months of telehealth integrated } \\
\text { care provided between April } 20 \\
\text { - July 26, 2020, with } \\
\text { conventional care provided } \\
\text { between January } 1 \text {, } 2018 \text { - } \\
\text { March } 22,2020 \text {. }\end{array}$ & $\begin{array}{l}\text { Telehealth's integrated } \\
\text { antenatal care enables a } \\
50 \% \text { reduction in in- } \\
\text { person consultations } \\
\text { without sacrificing } \\
\text { pregnancy outcomes. This } \\
\text { treatment model may help } \\
\text { minimize direct } \\
\text { interaction during the } \\
\text { COVID-19 pandemic, but } \\
\text { it should also be } \\
\text { considered in post- } \\
\text { pandemic health care } \\
\text { models. }\end{array}$ \\
\hline 2. & $\begin{array}{l}\text { Sanders, J., et al } \\
(2021)[3]\end{array}$ & $\begin{array}{l}\text { Anxious and } \\
\text { Traumatised : } \\
\text { Users' } \\
\text { Experiences of } \\
\text { Maternity Care in } \\
\text { the UK } \\
\text { During the } \\
\text { Covid-19 } \\
\text { Pandemic }\end{array}$ & $\begin{array}{l}\text { Design : Online } \\
\text { survey and } \\
\text { analysis } \\
\text { framework data } \\
\text { and descriptive } \\
\text { statistics. } \\
\text { Respondent : } \\
\text { Pregnant women } \\
\text { between June - } \\
\text { September } 2020 \\
\text { as many as } 524 \\
\text { pregnant women. }\end{array}$ & $\begin{array}{l}\text { An online survey (in } \\
\text { collaboration with WRISK's } \\
\text { Project Supervisory } \\
\text { Committee that includes } \\
\text { doctors, academics, and patient } \\
\text { representatives with extensive } \\
\text { experience) to explore user } \\
\text { experience of public health } \\
\text { facilities for pregnant women } \\
\text { during the Covid-19 pandemic } \\
\text { and antenatal, intrapartum and } \\
\text { postnatal care in maternity } \\
\text { services in } 4 \text { UK states. }\end{array}$ & $\begin{array}{l}\text { The survey found that } \\
\text { changes to antenatal } \\
\text { services led to unintended } \\
\text { negative consequences } \\
\text { including missed essential } \\
\text { clinical care. Mothers feel } \\
\text { their antenatal and } \\
\text { postnatal care is } \\
\text { inadequate and also } \\
\text { inflicts great emotional } \\
\text { harm on the user. }\end{array}$ \\
\hline 3. & $\begin{array}{l}\text { Lestari, K.P., } \\
\text { Muhamad } \\
\text { Jauhar, M. } \\
(2020)[4]\end{array}$ & $\begin{array}{l}\text { Improving } \\
\text { Pregnancy Care } \\
\text { during the } \\
\text { Covid-19 } \\
\text { Pandemic } \\
\text { for Pregnant } \\
\text { Women as } \\
\text { Vulnerable } \\
\text { Groups } \\
\text { Through } \\
\text { Assistance } \\
\text { at the Primary } \\
\text { Health Care } \\
\text { Facility }\end{array}$ & $\begin{array}{l}\text { Design : } \\
\text { Experimental } \\
\text { Design with } \\
\text { Pre-Posttest } \\
\text { without Control } \\
\text { Group. } \\
\text { Respondent : } \\
22 \text { pregnant } \\
\text { women in the } \\
\text { working area of } \\
\text { Padangsari } \\
\text { Health Center of } \\
\text { Semarang City } \\
\text { were selected by } \\
\text { purposive } \\
\text { sampling in } \\
\text { June-July } 2020 \\
\text { in face-to-face } \\
\text { and online } \\
\text { activities. }\end{array}$ & $\begin{array}{l}\text { The Smartphone app } \\
\text { "SEHARI" is used to share } \\
\text { modules and videos on } \\
\text { pregnancy health } \\
\text { guidelines. Furthermore, } \\
\text { these various research } \\
\text { activities include online } \\
\text { classes of pregnant women } \\
\text { through WhatsApp groups, } \\
\text { pregnancy care behavior } \\
\text { surveys, and evaluations. } \\
\text { Offline activities are carried } \\
\text { out in } 1 \mathrm{X} \text { meetings for 90- } \\
\text { 120 minutes, while online } \\
\text { activities are carried out as } \\
\text { needed. Questionnaires are } \\
\text { used to measure the } \\
\text { mother's behavior while } \\
\text { carrying out pregnancy care } \\
\text { and pregnancy examination } \\
\text { examinations. }\end{array}$ & $\begin{array}{l}\text { The results showed that } \\
59.1 \% \text { had pregnancy } \\
\text { examinations and visits. } \\
\text { Although including } \\
\text { vulnerable groups, } \\
\text { pregnant women should } \\
\text { still do pregnancy } \\
\text { checks in pandemic } \\
\text { times with strict health } \\
\text { protocols. Online } \\
\text { classes and specially } \\
\text { designed Smartphone } \\
\text { apps can be used as a } \\
\text { medium for delivering } \\
\text { essential health } \\
\text { messages so that } \\
\text { pregnant women can } \\
\text { still monitor their } \\
\text { pregnancy health and } \\
\text { have a way to bridge } \\
\text { existing programs in } \\
\text { primary health services. }\end{array}$ \\
\hline
\end{tabular}


TABLE 1 (CONTINUED)

\begin{tabular}{|c|c|c|c|c|c|}
\hline No & Author & Title & Method & Procedur & Result \\
\hline 4. & $\begin{array}{l}\text { Bradfield, Z., et } \\
\text { al (2020)[5] }\end{array}$ & $\begin{array}{l}\text { Experiences of } \\
\text { Receiving and } \\
\text { Providing } \\
\text { Maternity Care } \\
\text { during the Covid- } \\
19 \\
\text { Pandemic in } \\
\text { Australia: A Five- } \\
\text { Cohort Cross } \\
\text { Sectional } \\
\text { Comparison }\end{array}$ & $\begin{array}{l}\text { Design : Cross- } \\
\text { Sectional Studies. } \\
\text { Respondent : } \\
5 \text { main } \\
\text { stakeholder } \\
\text { groups are } \\
\text { women, women } \\
\text { partners, } \\
\text { midwives, } \\
\text { medical } \\
\text { practitioners and } \\
\text { midwifery } \\
\text { students who have } \\
\text { received or } \\
\text { provided care } \\
\text { from May } 13 \text { to } \\
\text { June } 24,2020 \text { in } \\
\text { Australia. }\end{array}$ & $\begin{array}{l}5 \text { key stakeholder groups that } \\
\text { have received or provided care } \\
\text { during the covid- } 19 \text { pandemic } \\
\text { across Australia via social } \\
\text { media and were invited to } \\
\text { participate in an online survey } \\
\text { released between May } 13 \text { and } \\
\text { June } 24,2020 \text {, a total of } 3701 \\
\text { full responses were received. }\end{array}$ & $\begin{array}{l}\text { Women are more likely to } \\
\text { show concerns about their } \\
\text { own health, safety and } \\
\text { family in relation to Covid- } \\
19 \text { whereas midwives, } \\
\text { doctors, and midwifery } \\
\text { students are more likely to } \\
\text { worry about occupational } \\
\text { exposure to Covid-19 } \\
\text { through working in a health } \\
\text { environment. Midwifery } \\
\text { students and female } \\
\text { partners feel more isolated } \\
\text { because of the changing } \\
\text { way care is provided. }\end{array}$ \\
\hline 5. & $\begin{array}{l}\text { Tadesse, E. } \\
(2020)[6]\end{array}$ & $\begin{array}{l}\text { Antenatal Care } \\
\text { Service } \\
\text { Utilization of } \\
\text { Pregnant Women } \\
\text { Attending } \\
\text { Antenatal Care in } \\
\text { Public Hospitals } \\
\text { during the Covid- } \\
19 \text { Pandemic } \\
\text { Period }\end{array}$ & $\begin{array}{l}\text { Design : Cross- } \\
\text { Sectional study } \\
\text { with simple } \\
\text { random sampling } \\
\text { technique. } \\
\text { Respondent : } \\
\text { Pregnant women } \\
\text { who attended } \\
\text { ANC services at } \\
\text { several public } \\
\text { hospitals in } \\
\text { Northeast Thiopia } \\
\text { from February } 2 \\
\text { to August } 30 \text {, } \\
2020 \text { as many as } \\
389 \text { pregnant } \\
\text { women. }\end{array}$ & $\begin{array}{l}\text { The data was collected using } \\
\text { questionnaires administered by } \\
\text { the interviewer. About six BSc } \\
\text { data-collecting nurses and } \\
\text { three public health watchdogs } \\
\text { were recruited in the data } \\
\text { collection. To ensure data } \\
\text { quality, } 2 \text { days of training is } \\
\text { provided for data collectors } \\
\text { and supervisors. In addition, } \\
\text { pretests are performed on } 10 \% \\
\text { of samples at Woldia General } \\
\text { Hospital prior to data retrieval } \\
\text { and there is close daily } \\
\text { monitoring of data collectors in } \\
\text { the data collection process. }\end{array}$ & $\begin{array}{l}3 \text { out of } 10 \text { pregnant women } \\
\text { who come to obstetric } \\
\text { polyclinics have made full } \\
\text { use of antenatal care } \\
\text { services. Encouraging } \\
\text { women's educational status, } \\
\text { prioritizing maternal health } \\
\text { services during Covid-19 } \\
\text { and improving the quality } \\
\text { of ANC services should be } \\
\text { further emphasized. }\end{array}$ \\
\hline 6. & $\begin{array}{l}\text { Goyal, M., et al } \\
(2020)[7]\end{array}$ & $\begin{array}{l}\text { The effect of the } \\
\text { Covid-19 } \\
\text { Pandemic on } \\
\text { Maternal Health } \\
\text { Due to Delay in } \\
\text { Seeking Health } \\
\text { Care: Experience } \\
\text { from a Tertiary } \\
\text { Center }\end{array}$ & $\begin{array}{l}\text { Design : An } \\
\text { Observational } \\
\text { Prospective Study } \\
\text { - Single Center. } \\
\text { Respondent : } \\
\text { All antenatal } \\
\text { women treated } \\
\text { from April - } \\
\text { August } 2020 \text { as } \\
\text { many as } 633 \\
\text { pregnant women. }\end{array}$ & $\begin{array}{l}\text { Data was collected on the } \\
\text { number of hospitalizations, } \\
\text { childbirths, antenatal visits, } \\
\text { reasons for unaffordable health } \\
\text { services, and complications } \\
\text { during pregnancy, compared to } \\
\text { data on the pre-Covid period of } \\
\text { October } 2019 \text { - February } 2020 \text {. }\end{array}$ & $\begin{array}{l}1 / 3 \text { of women have } \\
\text { inadequate antenatal visits. } \\
\text { The main reason for the } \\
\text { delay in health screenings } \\
\text { was lock down and fear of } \\
\text { contracting an infection that } \\
\text { resulted in } 44.7 \% \text { of } \\
\text { pregnancies with } \\
\text { complications. }\end{array}$ \\
\hline
\end{tabular}


TABLE 1 (CONTINUED)

\begin{tabular}{|c|c|c|c|c|c|}
\hline No & Author & Title & Method & Procedur & Result \\
\hline 7. & $\begin{array}{l}\text { Qomar, U.M., } \\
\text { dkk (2020)[8] }\end{array}$ & $\begin{array}{l}\text { Hubungan } \\
\text { Paritas, Umur dan } \\
\text { Usia Kehamilan } \\
\text { dengan Jarak } \\
\text { Kunjungan ANC } \\
\text { Trimester III di } \\
\text { Masa Pandemi } \\
\text { Covid-19 di PMB } \\
\text { Brida Kitty } \\
\text { Dinarum VWY }\end{array}$ & $\begin{array}{l}\text { Design : } \\
\text { Correlative } \\
\text { Descriptive } \\
\text { Research, with a } \\
\text { Cross Sectional } \\
\text { Approach. } \\
\text { Respondent : } \\
\text { Total sampling at } \\
\text { the research site } \\
\text { during May } 2020 \\
\text { as many as } 35 \\
\text { respondents } \\
\text { pregnant women. }\end{array}$ & $\begin{array}{l}\text { Pregnant women who } \\
\text { visited PMB Brida Kitty } \\
\text { Dinarum VWY entered } \\
\text { into the study sample } \\
\text { using questionnaire } \\
\text { measuring instruments and } \\
\text { observation sheets. }\end{array}$ & $\begin{array}{l}\text { The results showed from } 35 \\
\text { existing respondents that } \\
\text { antenatal care visits } \\
\text { respondents were } 80 \% \text { within } \\
1 \text { week. Bivariate analysis } \\
\text { showed that there was no } \\
\text { association between parity, } \\
\text { age and gestational age and } \\
\text { antenatal care visit distance } \\
\text { during the Covid } 19 \text { pandemic } \\
\text { with a value of } \alpha>0.05 \text {. It is } \\
\text { possible for pregnant women } \\
\text { to feel that the health of the } \\
\text { mother and fetus during } \\
\text { pregnancy is considered } \\
\text { important so that they } \\
\text { continue to make visits as } \\
\text { scheduled. In addition, the } \\
\text { readiness of PMB in } \\
\text { preventing the spread of covid } \\
\text { in accordance with } \\
\text { established health protocols } \\
\text { can be possible to make } \\
\text { respondents comfortable and } \\
\text { not feel afraid to make } \\
\text { antenatal care visits. }\end{array}$ \\
\hline 8. & $\begin{array}{l}\text { Ariestanti, Y., } \\
\text { dkk } \\
(2020)[9]\end{array}$ & $\begin{array}{l}\text { Determinan } \\
\text { Perilaku Ibu } \\
\text { Hamil Melakukan } \\
\text { Pemeriksaan } \\
\text { Kehamilan } \\
\text { (Antenatal Care) } \\
\text { Pada Masa } \\
\text { Pandemi Covid - } \\
19\end{array}$ & $\begin{array}{l}\text { Design : } \\
\text { Analytical Survey } \\
\text { uses a Cross } \\
\text { Sectional } \\
\text { Approach to } \\
\text { Accidental } \\
\text { Sampling. } \\
\text { Respondent : } \\
\text { A total of } 45 \\
\text { pregnant women } \\
\text { of TM } 3 \text { who did } \\
\text { ANC at PMB } \\
\text { Rosnawati in } \\
\text { March - October } \\
\text { 2020. }\end{array}$ & $\begin{array}{l}\text { Accidental sampling for } 1 \\
\text { month (September 3- } \\
\text { October 2020) amounted } \\
\text { to } 45 \text { people and all were } \\
\text { used as research samples / } \\
\text { total population. With a } \\
\text { questionnaire measuring } \\
\text { device. }\end{array}$ & $\begin{array}{l}\text { Research using Chi Square } \\
\text { analysis showed a value of } \\
\mathrm{P}<0.05 \text {, concluded there is a } \\
\text { significant relationship } \\
\text { between the behavior of } \\
\text { pregnant women doing ANC } \\
\text { with Age, Education, } \\
\text { Knowledge, Attitudes, and } \\
\text { Health Facilities. The Covid } \\
19 \text { pandemic does not prevent } \\
\text { pregnant women from } \\
\text { carrying out routine } \\
\text { pregnancy checks. }\end{array}$ \\
\hline 9. & $\begin{array}{l}\text { Refiani, D., dkk } \\
(2021)[10]\end{array}$ & $\begin{array}{l}\text { Gambaran } \\
\text { Perilaku Ibu } \\
\text { Hamil dalam } \\
\text { Melakukan } \\
\text { Antenatal Care } \\
\text { saat } \\
\text { Pandemi Covid- } \\
19 \text { di Puskesmas } \\
\text { Rawat Inap } \\
\text { Sidomulyo Kota } \\
\text { Pekanbaru }\end{array}$ & $\begin{array}{l}\text { Design : } \\
\text { Quantitative } \\
\text { descriptive. } \\
\text { Respondent : } 40 \\
\text { trimester III } \\
\text { pregnant women } \\
\text { who conducted } \\
\text { ANC } \\
\text { examinations } \\
\text { from November } \\
\text { 2020 to January } \\
\text { 2021 with } \\
\text { accidental } \\
\text { sampling } \\
\text { techniques. }\end{array}$ & $\begin{array}{l}\text { Data collection is done by } \\
\text { dividing google form links } \\
\text { to fill out research } \\
\text { questionnaires for } \\
\text { pregnant women who have } \\
\text { Whatsapp and do home } \\
\text { visits with the permission } \\
\text { of respondents first for } \\
\text { pregnant women who do } \\
\text { not have Whatsapp. }\end{array}$ & $\begin{array}{l}\text { The behavior of pregnant } \\
\text { women in conducting ANC } \\
\text { during the COVID-19 } \\
\text { pandemic showed almost } \\
\text { balanced results between } \\
\text { positive behavior as many as } \\
21 \text { respondents ( } 52.5 \% \text { ) and } \\
\text { negative behavior as many as } \\
19 \text { respondents ( } 47.5 \%) \text {. } \\
\text { Pregnant women, it is } \\
\text { important to increase their } \\
\text { awareness in determining } \\
\text { good behavior during } \\
\text { pregnancy in order to undergo } \\
\text { pregnancy and childbirth } \\
\text { well. }\end{array}$ \\
\hline
\end{tabular}


TABLE 1 (CONTINUED)

\begin{tabular}{|c|c|c|c|c|c|}
\hline No & Author & Title & Method & Procedur & Result \\
\hline 10. & $\begin{array}{l}\text { Datau, P.A.M. } \\
\text { (2020)[11] }\end{array}$ & $\begin{array}{l}\text { Intensitas } \\
\text { Kunjungan } \\
\text { Rumah Bidan } \\
\text { Desa pada Masa } \\
\text { Pandemi Covid- } \\
19 \text { terhadap } \\
\text { Ketepatam } \\
\text { Tindakan } \\
\text { Pemeriksaan pada } \\
\text { Ibu Hamil di } \\
\text { Wilayah } \\
\text { Puskesmas Sulili }\end{array}$ & $\begin{array}{l}\text { Design : } \\
\text { Analytical } \\
\text { Observational } \\
\text { Research with a } \\
\text { Cross-Sectional } \\
\text { Approach. } \\
\text { Respondent : All } \\
\text { pregnant women } \\
\text { TM 1-3 during the } \\
\text { Covid-19 } \\
\text { pandemic in } \\
\text { March - October } \\
\text { 2020 in the Sulili } \\
\text { Health Center area } \\
\text { as many as } 40 \\
\text { pregnant women. }\end{array}$ & $\begin{array}{l}\text { Data obtained or collected } \\
\text { from KIA books is then } \\
\text { analyzed using the Chi- } \\
\text { Square test. }\end{array}$ & $\begin{array}{l}\text { Of the } 40 \text { samples, the K1-K4 } \\
\text { examination visit was } \\
\text { conducted by not doing the } \\
\text { accuracy of the examination } \\
\text { action as many as } 22 \text { people } \\
(71 \%) \text { and the accuracy of the } \\
\text { examination action as many } \\
\text { as } 9 \text { people ( } 29 \%) \text {. While the } \\
\text { ki-K4 inspection visit was not } \\
\text { carried out with no accuracy } \\
\text { of the examination action as } \\
\text { many as } 9 \text { people ( } 29 \%) \text { and } \\
\text { the accuracy of the } \\
\text { examination was not obtained } \\
(0 \%) \text { Based on the results of } \\
\text { statistical tests obtained the } \\
\text { value p = } 0.090 \text { (p>0.05) } \\
\text { means the null hypothesis is } \\
\text { accepted. }\end{array}$ \\
\hline 11. & $\begin{array}{l}\text { Rizkia, M., dkk } \\
(2020)[12]\end{array}$ & $\begin{array}{l}\text { Hubungan } \\
\text { Pengetahuan } \\
\text { dengan Perilaku } \\
\text { Ibu Hamil dalam } \\
\text { Menjalani } \\
\text { Kehamilan } \\
\text { selama masa } \\
\text { Pandemi Covid- } \\
19\end{array}$ & $\begin{array}{l}\text { Design : } \\
\text { Descriptive } \\
\text { Explorative with a } \\
\text { Cross Sectional } \\
\text { Approach. } \\
\text { Respondent : } \\
\text { There were } 138 \\
\text { pregnant women } \\
\text { who were selected } \\
\text { as respondents } \\
\text { with a simple } \\
\text { random sampling } \\
\text { method. }\end{array}$ & $\begin{array}{l}\text { Data collection was } \\
\text { conducted in May } 2020 \\
\text { using an online custodist. } \\
\text { Then analyze the data } \\
\text { using the Chi-Square test. }\end{array}$ & $\begin{array}{l}\text { The results showed that there } \\
\text { is a relationship between } \\
\text { knowledge and maternal } \\
\text { behavior in undergoing } \\
\text { pregnancy during the Covid- } \\
19 \text { pandemic ( } \mathrm{p}=0.001) \text {. So } \\
\text { it can be concluded that } \\
\text { knowledge is an important } \\
\text { factor for pregnant women } \\
\text { because it can affect maternal } \\
\text { behavior during pregnancy. } \\
\text { So it is expected that optimal } \\
\text { education from health } \\
\text { workers. }\end{array}$ \\
\hline 12 & $\begin{array}{l}\text { Bugis, K.G. } \\
(2021)[13]\end{array}$ & $\begin{array}{l}\text { Faktor - faktor } \\
\text { yang } \\
\text { berhubungan } \\
\text { dengan } \\
\text { Kunjungan } \\
\text { Antenatal Care } \\
\text { (ANC) pada Ibu } \\
\text { Hamil selama } \\
\text { Masa Pandemi } \\
\text { Covid-19 di Kota } \\
\text { Makassar }\end{array}$ & $\begin{array}{l}\text { Design : } \\
\text { Quantitative } \\
\text { methods with } \\
\text { cross sectional } \\
\text { study design. } \\
\text { Respondent : The } \\
\text { sample in this } \\
\text { study amounted to } \\
255 \text { pregnant } \\
\text { women who } \\
\text { checked the } \\
\text { pregnancy at } \\
\text { Sudiang Raya } \\
\text { Health Center, } \\
\text { Balaparang Health } \\
\text { Center and Batua } \\
\text { City Health } \\
\text { Center makassar. }\end{array}$ & $\begin{array}{l}\text { The instruments in the } \\
\text { study used four } \\
\text { questionnaires: the } \\
\text { respondent's identity } \\
\text { questionnaire, the husband } \\
\text { support questionnaire, the } \\
\text { access affordability } \\
\text { questionnaire and the } \\
\text { Antenatal Care (ANC) } \\
\text { visit questionnaire during } \\
\text { the COVID-19 pandemic. }\end{array}$ & $\begin{array}{l}\text { Statistical test results using } \\
\text { the Chi-square test on } \\
\text { variables of parity and } \\
\text { support of husbands } \\
\text { consecutively obtained values } \\
\mathrm{p}=0.001 \text { and } \mathrm{p}=0.021 \\
\text { which means there is a } \\
\text { relationship between parity } \\
\text { and support of the husband } \\
\text { with antenatal care visits. } \\
\text { Conclusion: There is a } \\
\text { relationship between parity } \\
\text { and husband support and } \\
\text { antenatal care visits in } \\
\text { pregnant women during the } \\
\text { Covid-19 pandemic. }\end{array}$ \\
\hline
\end{tabular}

by 2 criteria, namely the emphasis of problems and the steps or research methods used, so that 12 studies were found.

Of the 12 studies obtained, the number of samples varied greatly from 22 to 2292 respondents. Statistical tests include Interrupted Time-Series Design, Online survey and descriptive statistics, Experiments with Pre-Posttest without and Lestari K.P et al who have implemented online-based health care methods, using smartphone applications specifically designed to be used as a message delivery media, after seeing the results of the implementation it is expected that there is a change in the behavior of pregnant women to conduct examinations while adhering to health protocols 
during the covid-19 pandemic. In other studies mentioned that parity, age, gestational age, knowledge, education, attitudes, family support and health facilities are important factors for pregnant women because they can affect maternal behavior during pregnancy.

So it is expected that optimal education from health workers. This is in accordance with the results of several articles namely Qomar, U.M., et al, Ariestanti, Y., et al, Rizkia, M., et al and Bugis, K.G. where their research results stated that there was no influence of the covid-19 pandemic with the results of antenatal care of pregnant women.[21], [22], [25], [26].

\section{CONCLUSION}

The Covid-19 pandemic made universal, radical, and very rapid changes to the health services of many countries around the world, especially obstetrics.[16] Since its discovery in December 2019, Coronavirus Disease 2019 (COVID-19) has spread from Wuhan, China, to many other countries. A rapid increase of newly discovered cases was observed, and finally, in March 2020, the World Health Organization declared that Coronavirus Disease 2019 (Covid-19) was a global pandemic. As one of the vulnerable groups, pregnant women need to avoid Covid-19 transmission and maintain their health in the pandemic period.[17]

From the literature study studied, there were $66.7 \%$ that resulted in irregularities in antenatal care visits conducted by pregnant women both in PMB and Hospital. This happens for several reasons including fear of contracting a viral infection and harming the fetus, so pregnant women prefer to stay at home and not get their pregnancy checked.

To reduce direct interaction during the Covid-19 pandemic, we can apply online-based health care methods as a medium for delivery of essential health messages so that pregnant women and health workers can still monitor their pregnancy health and get information related to their pregnancy. As has been done in palmar research K.R et al and Lestari K.P et al who have implemented online-based health care methods, using smartphone applications specifically designed to be used as a message delivery media, after seeing the results of the implementation it is expected that there is a change in the behavior of pregnant women to conduct examinations while adhering to health protocols during the covid-19 pandemic.

In other studies mentioned that parity, age, gestational age, knowledge, education, attitudes, family support and health facilities are important factors for pregnant women because they can affect maternal behavior during pregnancy. So it is expected that optimal education from health workers. This is in accordance with the results of several articles namely Qomar, U.M., et al, Ariestanti, Y., et al, Rizkia, M., et al and Bugis, K.G. where their research results stated that there was no influence of the covid-19 pandemic with the results of antenatal care of pregnant women.[21], [22], [25], [26].

\section{REFERENCES}

[1] J. M. Wu, Z., \& Mcgoogan, "Characteristics of and Important Lessons from the Coronavirus Disease 2019 (COVID-19) Outbreak in China: Summary of a Report of 72314 Cases from the Chinese Center for Disease Control and Prevention," JAMA-Journal Am. Med. Assoc., vol. 323, no. 13, pp. 1239-1242, 2020

[2] A. Yunus, N.R., Rezki, "Kebijakan Pemberlakuan Lock Down Sebagai Antisipasi Penyebaran Corona Virus COVID-19,” Salam J. Sos. dan Budaya Syar'i, vol. 7, no. 3, 2020.

[3] F. Guner, R., Hasanoglu, I., \& Aktas, "Covid-19: Prevention and control measures in community," Turkish J. Med. Sci., vol. 50, no. SI-1, pp. 571-577, 2020.

[4] N. Nurhalimah, "Upaya Bela Negara Melalui Sosial Distancing Dan Lockdown Untuk Mengatasi Wabah Covid-19 (Efforts to Defend the Country Through Social Distancing and Lockdown to Overcome the COVID-19 Plague)," SSRN Electron. J., vol. 19, 2020.

[5] Worldometer, "Coronavirus Update (Live): 90,702,906 Cases and 1,943,432 Deaths from COVID-19 Virus Pandemic," 2021.

[6] Dinkes Jatim, Data Pandemi Covid: Profil Kesehatan Provinsi Jatim. Surabaya: Dinas Kesehatan Provinsi Jawa Timur, 2021.

[7] R. Shereen, M. A., Khan, S., Kazmi, A., Bashir, N., \& Siddique, "COVID-19 infection: Origin, transmission, and characteristics of human coronaviruses," J. Adv. Res., vol. 24, no. 1, pp. 91-98, 2020

[8] L. Guan, W., Ni, Z., Hu, Y., Liang, W., Ou, C., He, J., Lu, L., Shan, H., Lei, C.L., Hui, D.S.C., Du, B., Li, "Clinical characteristics of coronavirus disease 2019 in China," N. Engl. J. Med., vol. 382, no. 18, pp. 1708-1720, 2020.

[9] L. Di Gennaro, F., Pizzol, D., Marotta, C., Antunes, M., Racalbuto, V., Veronese, N., \& Smith, "Coronavirus diseases (COVID-19) current status and future perspectives: A narrative review," Int. J. Environ. Res. Public Health, vol. 17, no. 8, p. 2690, 2020.

[10] L. Rukiah, A.Y., Yulianti, Asuhan Kebidanan 1 Kehamilan. Jakarta: Trans Info Media, 2009

[11] Kementrian Kesehatan RI, Profil Kesehatan Indonesia 2017. Jakarta: Kemenkes RI, 2018

[12] H. Khan, S., Zeb, F., Shoaib, M., Haq, I. U. L., Xu, K., \& Li, "Selected Micronutrients: An Option to Boost Immunity against COVID-19 and Prevent Adverse Pregnancy Outcomes in Pregnant Women : A Narrative Review," Iran Public Heal., vol. 49, no. 11, pp. 2032- 2043, 2020

[13] P. Samji, "Coronavirus Disease (COVID-19) - Risk to Pregnant Women," 2020.

[14] E. M. Mar'ah, "Tunaikan Layanan Kesehatan Ibu dan Anak di Masa Pandemi Covid19," Indones. J. Community Heal. Nurs. (Jurnal Keperawatan Komunitas), vol. 5, no. 2, pp. 23-28, 2020.

[15] R. J. Palmar, K.R., Davies-Tuck, M., Rindt, A., Papacostas, K., Giles, M.L., Brown, K., Diamandis, H., Fradkin, R., Stewart, A.E., Rolnik, D.L., Stripp, A., Wallace, E.M., Mol, B.W., Hodges, "Widespread Implementation of A Low-Cost Telehealth Service in the Delivery of Antenatal Care During the Covid-19 Pandemic: an Interrupted Time-Series Analysis," NEJM J. Watch, vol. 398, no. 10294, pp. 41-52, 2021

[16] R. Sanders, J., Blaylock, "Anxious and Traumatised: Users' Experiences of Maternity Care in the UK During the Covid-19 Pandemic," Elsevier Ltd, vol. 102, no. 103069, 2021.

[17] M. Lestari, K.P., Jauhar, "Improving Pregnancy Care during the Covid-19 Pandemic for Pregnant Women as Vulnerable Groups Through Assistance at the Primary Health Care Facility," J. Community Empower. Heal., vol. 4, no. 1, pp. 29-36, 2020.

[18] L. Bradfield, Z., Wynter, K., Hauck, Y., Vasilevski, V., Kuliukas, L., Wilson, A.N., Szabo, R.A., Homer, C.S.E., Sweet, "Experiences of Receiving and Providing Maternity Care during the Covid-19 Pandemic in Australia: A Five-Cohort Cross Sectional Comparison," PLoS One, vol. 16, no. 3, 2020.

[19] E. Tadesse, "Antenatal Care Service Utilization of Pregnant Women Attending Antenatal Care in Public Hospitals during the Covid-19 Pandemic Period," Int. J. Women's Heal., vol. 12, pp. 1181-1188, 2020.

[20] S. Goyal, M., Singh, P., Singh, K., Shekhar, S., Agrawal, N., Misra, [1] J. M. Wu, Z., \& Mcgoogan, "Characteristics of and Important 
Lessons from the Coronavirus Disease 2019 (COVID-19) Outbreak in China: Summary of a Report of 72314 Cases from the Chinese Center for Disease Control and Prevention," JAMA-Journal Am. Med. Assoc., vol. 323, no. 13, pp. 1239-1242, 2020.

[21] B. K. D. V. W. Qomar, U.M., Na'mah, L.U., Yelvin, "Hubungan Paritas, Umur dan Usia Kehamilan dengan Jarak Kunjungan ANC Trimester III di Masa Pandemi Covid-19 di PMB Brida Kitty Dinarum VWY," J. Ilm. Kesehat. Keperawatan, vol. 16, no. 2, pp. 133-136, 2020.

[22] Y. Ariestanti, Y., Widayati, T., Sulistyowati, "Determinan Perilaku Ibu Hamil Melakukan Pemeriksaan Kehamilan (Antenatal Care) Pada Masa Pandemi Covid -19,” J. Bid. Ilmu Kesehat., vol. 10, no. 2, pp. 203-216, 2020

[23] S. Refiani, D., Dewi, Y.I., Utami, "Gambaran Perilaku Ibu Hamil dalam Melakukan Antenatal Care saat Pandemi Covid-19 di Puskesmas Rawat Inap Sidomulyo Kota Pekanbaru," Heal. Inf. J. Penelit., vol. 3, no. 2, 2021.

[24] P. A. M. Datau, "Intensitas Kunjungan Rumah Bidan Desa pada Masa Pandemi Covid-19 terhadap Ketepatam Tindakan Pemeriksaan pada Ibu Hamil di Wilayah Puskesmas Sulili," Universitas Muhammadiyah Makassar, 2020.

[25] N. Rizkia, M., Kiftia, M., Ardhia, D., Darmawati., Fitri, A., Fajri, "Hubungan Pengetahuan dengan Perilaku Ibu Hamil dalam Menjalani Kehamilan selama masa Pandemi Covid-19," J. Keperawatan Malang, vol. 5, no. 2, pp. 80-86, 2020.

[26] K. G. Bugis, "Faktor - faktor yang berhubungan dengan Kunjungan Antenatal Care (ANC) pada Ibu Hamil selama Masa Pandemi Covid-19 di Kota Makassar," Universitas Hasanuddin, 2021.

[1] D. Budiman and C. Chu, "A SWOT Analysis of Indonesia's COVID-19 Pandemic Response Strategy," Int. J. Adv. Heal. Sci. Technol., vol. 1, no. 2, pp. 50-52, 2021.

[2] R. J. Palmar, K.R., Davies-Tuck, M., Rindt, A., Papacostas, K., Giles, M.L., Brown, K., Diamandis, H., Fradkin, R., Stewart, A.E., Rolnik, D.L., Stripp, A., Wallace, E.M., Mol, B.W., Hodges, "Widespread Implementation of A Low-Cost Telehealth Service in the Delivery of Antenatal Care During the Covid-19 Pandemic: an Interrupted Time-Series Analysis," NEJM J. Watch, vol. 398, no. 10294, pp. 41-52, 2021.

[3] R. Sanders, J., Blaylock, "Anxious and Traumatised : Users' Experiences of Maternity Care in the UK During the Covid-19 Pandemic," Elsevier Ltd, vol. 102, no. 103069, 2021.

[4] M. Lestari, K.P., Jauhar, "Improving Pregnancy Care during the Covid-19 Pandemic for Pregnant Women as Vulnerable Groups Through Assistance at the Primary Health Care Facility," $J$. Community Empower. Heal., vol. 4, no. 1, pp. 29-36, 2020.

[5] L. Bradfield, Z., Wynter, K., Hauck, Y., Vasilevski, V., Kuliukas, L., Wilson, A.N., Szabo, R.A., Homer, C.S.E., Sweet, "Experiences of Receiving and Providing Maternity Care during the Covid-19 Pandemic in Australia: A Five-Cohort Cross Sectional Comparison," PLoS One, vol. 16, no. 3, 2020.

[6] E. Tadesse, "Antenatal Care Service Utilization of Pregnant Women Attending Antenatal Care in Public Hospitals during the Covid-19 Pandemic Period," Int. J. Women's H eal., vol. 12, pp. 1181-1188, 2020.

[7] S. Goyal, M., Singh, P., Singh, K., Shekhar, S., Agrawal, N., Misra, "The effect of the Covid-19 Pandemic on Maternal Health Due to Delay in Seeking Health Care: Experience from a Tertiary Center," Int. J. Obs. Gynaecol., vol. 20152, no. 2, pp. 231-235, 2020.

[8] B. K. D. V. W. Qomar, U.M., Na'mah, L.U., Yelvin, "Hubungan Paritas, Umur dan Usia Kehamilan dengan Jarak Kunjungan ANC Trimester III di Masa Pandemi Covid-19 di PMB Brida Kitty Dinarum VWY," J. Ilm. Kesehat. Keperawatan, vol. 16, no. 2, pp. 133-136, 2020.

[9] Y. Ariestanti, Y., Widayati, T., Sulistyowati, "Determinan Perilaku Ibu Hamil Melakukan Pemeriksaan Kehamilan (Antenatal Care) Pada Masa Pandemi Covid -19," J. Bid. Ilmu Kesehat., vol. 10, no. 2, pp. 203-216, 2020.

[10] S. Refiani, D., Dewi, Y.I., Utami, "Gambaran Perilaku Ibu Hamil dalam Melakukan Antenatal Care saat Pandemi Covid-19 di Puskesmas Rawat Inap Sidomulyo Kota Pekanbaru,” Heal.
[11] P. A. M. Datau, "Intensitas Kunjungan Rumah Bidan Desa pada Masa Pandemi Covid-19 terhadap Ketepatam Tindakan Pemeriksaan pada Ibu Hamil di Wilayah Puskesmas Sulili," Universitas Muhammadiyah Makassar, 2020.

[12] N. Rizkia, M., Kiftia, M., Ardhia, D., Darmawati., Fitri, A., Fajri, "Hubungan Pengetahuan dengan Perilaku Ibu Hamil dalam Menjalani Kehamilan selama masa Pandemi Covid-19," J. Keperawatan Malang, vol. 5, no. 2, pp. 80-86, 2020.

[13] K. G. Bugis, "Faktor - faktor yang berhubungan dengan Kunjungan Antenatal Care (ANC) pada Ibu Hamil selama Masa Pandemi Covid-19 di Kota Makassar," Universitas Hasanuddin, 2021. 